\title{
Study of Nutrient Foramina of Human Radii of Saurashtra Region
}

\author{
V. J. Akbari ${ }^{1}$, Sanjay Chavda ${ }^{2}$, Ashish Rathva ${ }^{3}$ \\ ${ }^{1}$ Assistant Professor, Department of Anatomy, G.M.E.R.S. Medical College, Junagadh. ${ }^{2}$ Assistant Professor, Department of Anatomy, P.D.U. Medical \\ College, Rajkot, Gujarat, India, ${ }^{3}$ Tutor, Department of Anatomy, P.D.U. Medical College, Rajkot, Gujarat, India.
}

\section{Abstract}

Introduction: In long bones including radius, surface opening of nutrient canal is known as nutrient foramen, which transmits nutrient artery to supply cortical bone and medullary cavity. Topographical information about nutrient foramen is very crucial during various orthopedic surgical procedures. Objective: Present study was conducted to study number of nutrient foramina, its location and direction in relation to growing end of bone and to calculate foraminal index of human radius. Subjects and Methods: In present study 63(31 right and 32 left sided) radii bone of unknown age and sex were studied. Only fully intact bone without any disease were included. Surface location and direction of nutrient foramina were recorded. Total length of radius was measured with osteomatric board. Distance of nutrient foramen from proximal end was measured with digital vernier caliper. And foraminal index was calculated. All data was tabulated and analyzed statistically. Results: All radii had single nutrient foramen. Majority $(82.54 \%)$ of the nutrient foramina were detected on the anterior surface, $14.29 \%$ were on posterior surface and only two bone have nutrient foramen on other surface. Zone I contained $30.16 \%$ and Zone II contained $66.67 \%$ and Zone III contained $3.17 \%$ foramina. Direction of all foramina were towards upper end of radius except two bones. Conclusion: Almost all the results coincided with previous studies from different geographical regions. Thorough knowledge of morphology of nutrient foramina is necessary for preserving circulation. Because it is very crucial in bone grafting, fracture healing, joint replacement therapy and vascularized bone micro surgeries.

Keywords: Radius, Foraminal Index, Nutrient Foramen, Fracture, Morphometry.

Corresponding Author: Dr. Sanjay Chavda, Department of Anatomy, P.D.U. Govt. Medical College, Rajkot-360001

Received: March 2019

Accepted: March 2019

\section{Introduction}

Radius is the lateral bone of forearm and is homologus with the tibia of the lower limb. ${ }^{[1]}$ Shaft of appendicular long bones are usually supplied by one or two arteries known as nutrient arteries. Nutrient arteries enters in the bone through nutrient foramina to travel through nutrient canal and provide blood supply to inner cortex and medullary cavity of long bone. Surface opening of nutrient canal is called nutrient foramen. ${ }^{[2]}$ Nutrient canal is directed obliquely, so on surface of bone nutrient foramen is also obliquely placed and directed toward one of the end of the bone. Generally nutrient foramen is directed away from growing end but it is not always the case. The topographical knowledge of nutrient foramina is very crucial in operative procedures particularly in orthopedic surgeries to preserve the circulation. ${ }^{[3]}$ Nutrient arteries must be preserved in bone grafting, fracture healing joint replacement and vascularized bone micro surgeries. ${ }^{[4-5]}$ In Radius Nutrient foramen is usually single and located at middle of its anterior surface and directed toward upper end of bone. ${ }^{[6]}$

Aim of present study was to observe and measure the nutrient foramina of radii of saurashtra region and to find out that observation coincides or differs from other studies.

\section{Subjects and Methods}

In this study 63 dry human radii of unknown age and sex (31 right and 32 left sided) from Department of Anatomy, P.D.U.Medical College, Rajkot were added. The bones having gross pathological deformities and damaged and unossified bones were excluded from the study. In each bone surfaces of shaft were observed with hand lens to find out nutrient foramina. Criteria for identification of foramen were a bony groove leading to foramen and diameter of foramen. Diameter were measured by inserting needles of various gauge. [Figure 1]. Foramina allowing insertion of 24 gauge or thicker needle were noted and studies. Total length of bone was measured with osteometric board. [Figure 3]. Distance between proximal end of radius and nutrient foramen (DNF) was measured with digital vernier caliper. [Figure 2]. It was measured from upper surface of head of radius to margin of nutrient foramen. Then Foraminal index was calculated using formula $\mathrm{FI}=(\mathrm{DNF} / \mathrm{TL}) \times 100$ by Hughes $1952,{ }^{[7]}$ and Shulman $1959,{ }^{[8]}$ where FI is Foraminal Index, TL is total length of radius and DNF is distance of proximal end of radius from nutrient foramen. Location of nutrient foramen on shaft was classified in three Zones by 


\section{Akbari et al; Study of Nutrient Foramina of Htuman Radit}

value of foraminal index. Zone-I: FI less than 33.33, foramen in upper 1/3rd of shaft, Zone-II: FI between 33.33 and 66.66, foramen in middle 1/3rd of shaft, Zone-III: FI more than 66.66 foramen in lower 1/3rd of shaft. All the data was tabulated and analyzed statistically.

\section{Results}

Data of number of nutrient foramen in radius is tabulated in Table-1.In this study we observed that all radius had only one nutrient foramen.

Table 1: Number of nutrient foramina of radius.

\begin{tabular}{|c|c|c|c|c|c|c|}
\hline \multirow{2}{*}{$\begin{array}{l}\text { No of } \\
\text { nutrient } \\
\text { foramen }\end{array}$} & \multicolumn{2}{|l|}{ Right } & \multicolumn{2}{|l|}{ Left } & \multicolumn{2}{|l|}{ Total } \\
\hline & $\begin{array}{l}\text { No. of } \\
\text { Radius }\end{array}$ & $\%$ & $\begin{array}{l}\text { No. of } \\
\text { Radius }\end{array}$ & $\%$ & $\begin{array}{l}\text { No. of } \\
\text { Radius }\end{array}$ & $\%$ \\
\hline 0 & 00 & 00 & 00 & 00 & 00 & 00 \\
\hline 1 & 31 & 100 & 32 & 100 & 63 & 100 \\
\hline 2 & 00 & 00 & 00 & 00 & 00 & 00 \\
\hline Total & 31 & 100 & 32 & 100 & 63 & 100 \\
\hline
\end{tabular}

As [Table 2] shows, in this study we found that $82.54 \%$ of radius have nutrient foramen on its anterior surface, $14.29 \%$ of radius have foramen on posterior surface. Only one bone of right side have nutrient foramen on lateral surface and one having foramen on interosseus border.

Table 2: Location of nutrient foramen (NF) of radius.

\begin{tabular}{|c|c|c|c|c|c|c|}
\hline \multirow{2}{*}{$\begin{array}{l}\text { Location } \\
\text { of NF }\end{array}$} & \multicolumn{2}{|l|}{ Right } & \multicolumn{2}{|l|}{ Left } & \multicolumn{2}{|l|}{ Total } \\
\hline & $\begin{array}{l}\text { No. of } \\
\text { radius }\end{array}$ & $\%$ & $\begin{array}{l}\text { No. of } \\
\text { radius }\end{array}$ & $\%$ & $\begin{array}{l}\text { No. of } \\
\text { radius }\end{array}$ & $\%$ \\
\hline $\begin{array}{l}\text { Anterior } \\
\text { Surface }\end{array}$ & 26 & 83.87 & 26 & 81.25 & 52 & 82.54 \\
\hline $\begin{array}{l}\text { Posterior } \\
\text { Surface }\end{array}$ & 3 & 9.68 & 6 & 18.75 & 9 & 14.29 \\
\hline $\begin{array}{l}\text { Lateral } \\
\text { surface }\end{array}$ & 1 & 3.22 & 0 & 00 & 1 & 1.59 \\
\hline $\begin{array}{l}\text { Interosseus } \\
\text { border }\end{array}$ & 1 & 3.22 & 0 & 00 & 1 & 1.59 \\
\hline
\end{tabular}

[Table 3] shows that $30.16 \%$ of radii have foramen in upper $1 / 3$ rd of shaft , $66.67 \%$ of radii have foramen in middle $1 / 3$ rd of shaft and $3.17 \%$ radii have foramen in lower $1 / 3 \mathrm{rd}$ of shaft.

Table 3: Showing distribution of nutrient foramen in respect to
zone of Radius
\begin{tabular}{|l|l|l|l|l|l|l|}
\hline Zone & Right (31) & Left (32) & \multicolumn{2}{l|}{ Total (63) } \\
\hline & Number & $\%$ & Number & $\%$ & Number & $\%$ \\
\hline $\begin{array}{l}\text { Zone } \\
\text { I }\end{array}$ & 7 & 22.58 & 12 & 37.5 & 19 & 30.16 \\
\hline $\begin{array}{l}\text { Zone } \\
\text { II }\end{array}$ & 23 & 74.19 & 19 & 59.38 & 42 & 66.67 \\
\hline $\begin{array}{l}\text { zone } \\
\text { III }\end{array}$ & 01 & 03.23 & 01 & 03.12 & 02 & 03.17 \\
\hline
\end{tabular}

Nutrient foramina were directed towards the upper end of all radii [Figure 1] except two bone having foramina directed towards lower end.

[Table 4] shows the mean value and standard deviation (SD) and range of values of TL, DNF and foraminal index of radius. Total length of radius have mean $\pm S D$ of $24 \pm 2.12 \mathrm{~cm}$ $\mathrm{cm}$; DNF have mean \pm SD of $8.65 \pm 1.76 \mathrm{~cm}$ and foraminal index have mean \pm SD of $36.14 \pm 7.11 \%$.
Table 4: Mean values, SD and range of statistical measurements of nutrient foramina of radius.

\begin{tabular}{|l|l|l|l|}
\hline Parametre & Right 31 & Left 32 & Total 63 \\
\hline $\begin{array}{l}\text { Mean } \pm \text { SD of } \\
\text { TL }\end{array}$ & $24.06 \pm 2.18 \mathrm{~cm}$ & $23.89 \pm 2.10 \mathrm{~cm}$ & $24 \pm 2.12 \mathrm{~cm}$ \\
\hline Range of TL & $20.4-30.5 \mathrm{~cm}$ & $20.7-29.9 \mathrm{~cm}$ & $20.4-30.5 \mathrm{~cm}$ \\
\hline $\begin{array}{l}\text { Mean } \pm \text { SD of } \\
\text { DNF }\end{array}$ & $8.94 \pm 2.11 \mathrm{~cm}$ & $8.38 \pm 1.33 \mathrm{~cm}$ & $8.65 \pm 1.76 \mathrm{~cm}$ \\
\hline Range of DNF & $6.18-17.81 \mathrm{~cm}$ & $6.22-12.06 \mathrm{~cm}$ & $\begin{array}{l}6.18-12.06 \\
\mathrm{~cm}\end{array}$ \\
\hline $\begin{array}{l}\text { Mean } \pm \text { SD of } \\
\text { FI }\end{array}$ & $37.27 \pm 8.54 \%$ & $35.18 \pm 5.36 \%$ & $36.14 \pm 7.11 \%$ \\
\hline Range of FI & $22.46-72.99 \%$ & $27.86-88 \%$ & $22.46-88 \%$ \\
\hline
\end{tabular}

$\mathrm{TL}=$ total length, $\mathrm{DNF}=$ Distance from proximal end to NF,FI= Foraminal Index

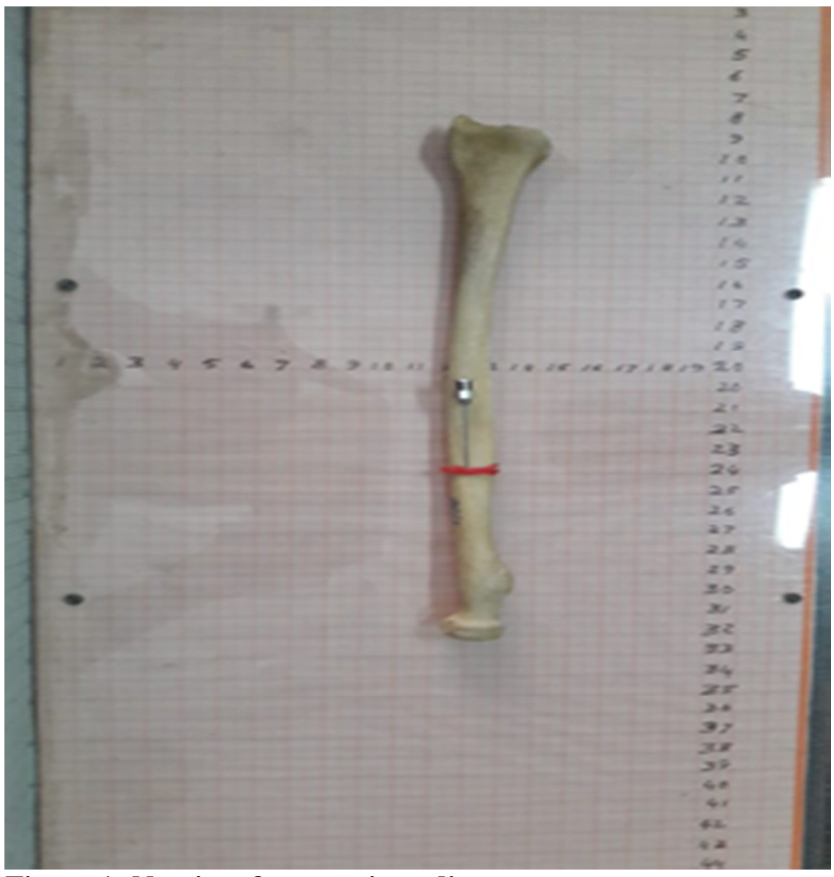

Figure 1: Nutrient foramen in radius

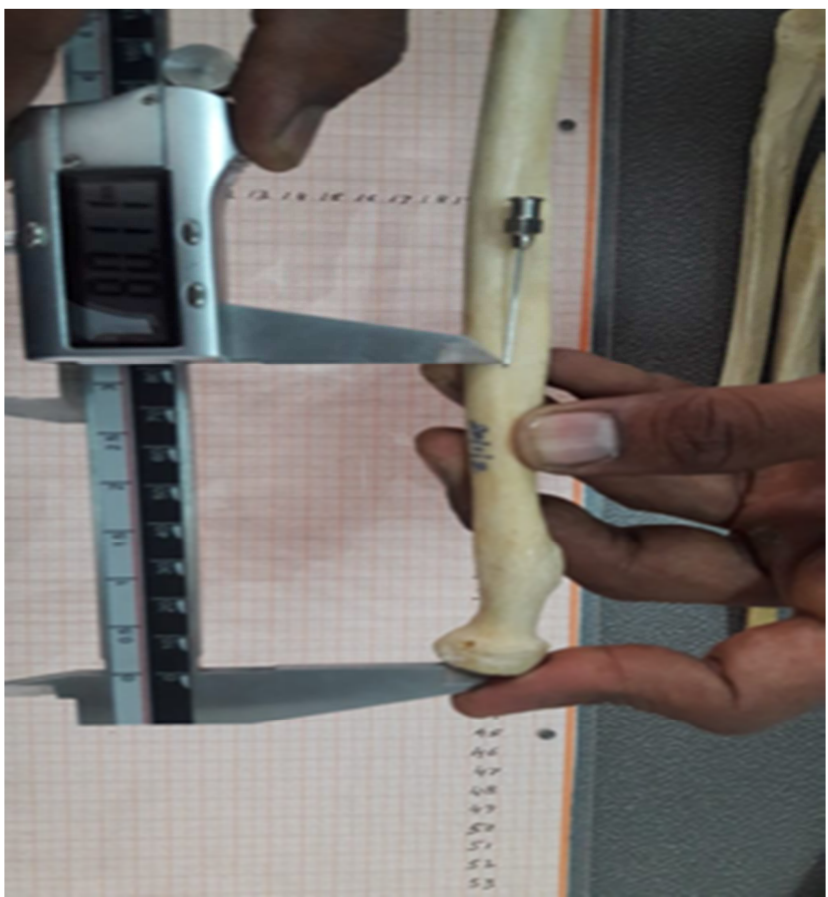

Figure 2: Measuring DNF 


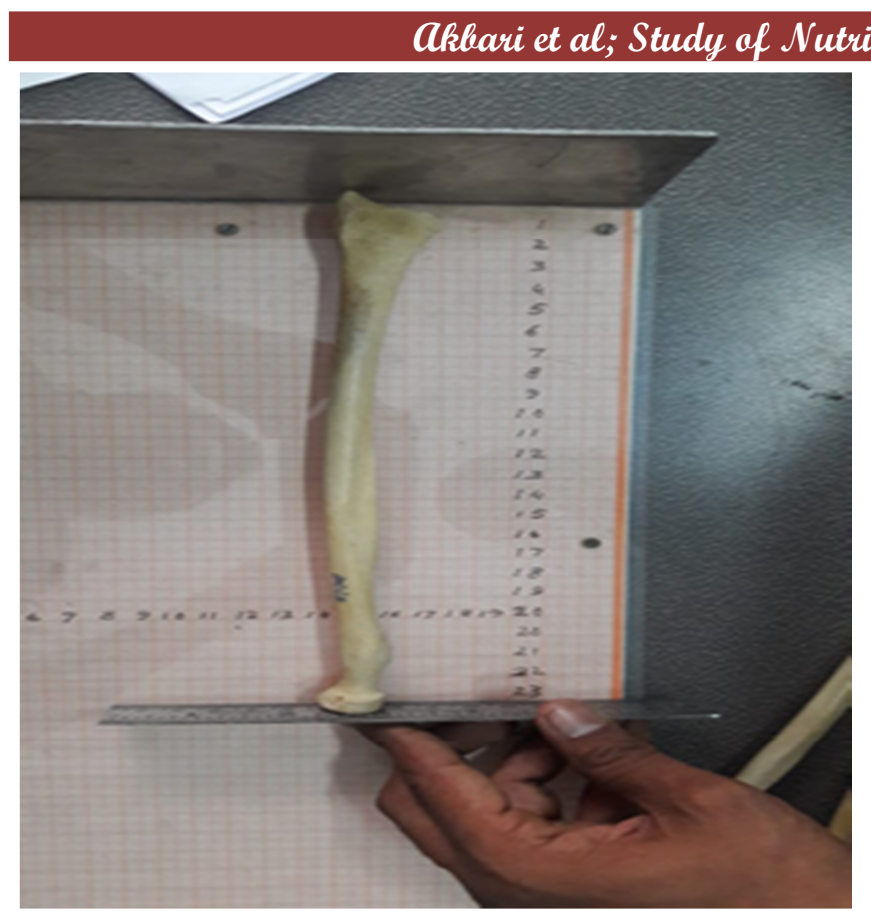

Fig 3 Measuring total length of radius

\section{Discussion \& Conclusion}

\section{Number of nutrient foramina}

All the radii had single nutrient foramen. Which correspond with other studies on radius like Pereira et al, ${ }^{[9]}$ Dr. Mani Arora and Swati Shah1 et al. ${ }^{[10,11]}$

\section{Direction of nutrient foramen}

All nutrient foramina were directed towards upper end of radius except two bones which correlates with other studies.

\section{Position of nutrient foramina}

In $66.67 \%$ radii foramina were lying on middle $3 \mathrm{rd}$ of shaft and in $30.16 \%$ on upper 3rd of shaft. In this study mean and SD of foraminal index was $36.14 \pm 7.11 \%$. These results are confirmatory with the other studies like Forriol Campos F et al, ${ }^{[12]}$ Pereira et al. ${ }^{[9]}$

\section{Clinical relevance}

Morphometry of nutrient foramina in long bones is very important in surgical procedures like joint replacement therapy, fracture repair, bone grafts and vascularized bone microsurgery. During fracture and dislocation nutrient arteries get commonly injured. During treatment of fracture and dislocation due care must be taken to prevent injury to nutrient artery. So this study will help orthopedic surgeons regarding number and position of nutrient arteries of radius.

\section{References}

1. B.D. Chaurasia's Human Anatomy Volume -1, 6th Edition: p15

2. Fraizer, Ernest J. The Anatomy of Human Skeleton 4th Edition (1964).p5

3. Mysorekar VR, Diaphysial nutrient foramina in human long bones, J Anat, 1967, 101(Pt 4):813-822.

4. Raj Kumar, Raghuveer Singh Mandloi, Alok Kumar Singh, Devesh Kumar, Pawan Mahato; Analytical and morphometric study of nutrient foramina of femur in rohilkhand region. Innovative J Med Health Sci 2013;3(2):52-4.

5. Longia GS, Ajmani ML, Saxena SK, Thomas RJ- Study of diaphyseal nutrient foramina in human long bones. Acta Anat 1980;107:399-406

6. Susan Standring, Gray's Anatomy, 40th edition

7. Hughes $\mathrm{H}$. The factors determining the direction of canal for the nutrient artery in the long bones of mammals and birds. Acta Anat 1952;15(3):261-80.

8. S. S. Shulman, Observations on the nutrient foramina of the human radius and ulna; The anatomical record 1959;134(4):68597.

9. Pereira, G. A. M.; Lopes, P. T. C.; Santos, A. M. P. V. \& Silveira, F. H. S.,Nutrient Foramina in the Upper and Lower Limb Long Bones: Morphometric Study in Bones of Southern Brazilian Adults, Int. J. Morphol., 29(2):514-520, 2011

10. Dr. Mani Arora, Morphometric study of nutrient foramina of human radii and their surgical Importance, Indian Journal of Basic \& Applied Medical Research; December 2011: Issue-1, Vol.-1, P. 86-91

11. Swati Shah, Shaista Saiyad, Morphometric study of nutrient foramina of 200 human radii IN GUJARAT, J of Evolution of Med and Dent Sci/ Vol. 3/ Issue 57/Oct 30, 2014 p 12997-13002

12. Forriol Campos F, Gomez L, Gianonatti M, Fernandez R. A study of the nutrient foramina in human long bones. Surg Radil Anat. $1987 ; 9: 251-25$

Copyright: ( $)$ the author(s), publisher. Academia Anatomica International is an Official Publication of "Society for Health Care \& Research Development". It is an open-access article distributed under the terms of the Creative Commons Attribution Non-Commercial License, which permits unrestricted non-commercial use, distribution, and reproduction in any medium, provided the original work is properly cited.

How to cite this article: Akbari VJ, Chavda S, Rathva A. Study of Nutrient Foramina of Human Radii of Saurashtra Region. Acad. Anat. Int. 2019;5(1):79-81.

DOI: dx.doi.org/10.21276/aanat.2019.5.1.18

Source of Support: Nil, Conflict of Interest: None declared 